German Modernism 
CALIFORNIA STUDIES IN 2OTH-CENTURY MUSIC

Richard Taruskin, General Editor

I. Revealing Masks: Exotic Influences and Ritualized Performance in Modernist Music Theater, by W. Anthony Sheppard

2. Russian Opera and the Symbolist Movement, by Simon Morrison

3. German Modernism: Music and the Arts, by Walter Frisch 


\title{
German Modernism
}

MUSIC AND THE ARTS

\author{
Walter Frisch
}

UNIVERSITY OF CALIFORNIA PRESS BERKELEY LOS ANGELES LONDON 
The publisher gratefully acknowledges the generous contribution to this book provided by the Ahmanson Foundation Humanities Endowment Fund of the University of California Press Associates.

University of California Press Berkeley and Los Angeles, California

University of California Press, Ltd. London, England

(C) 2005 by The Regents of the University of California

Library of Congress Cataloging-in-Publication Data

Frisch, Walter, 195I-.

German modernism : music and the arts / Walter Frisch.

p. $\quad \mathrm{cm} .-$ (California studies in 2oth-century music ; 3)

Includes bibliographical references and index.

ISBN 0-520-2430I-3 (cloth : alk. paper).

I. Music-Germany-19th century-History and criticism. 2. Music-Germany-2oth centuryHistory and criticism. 3. Modernism (Art) Germany. 4. Art and music. I. Title. II. Series.

ML275.F75 2005

780'.943'09034-dc22 2004012678

Manufactured in the United States of America

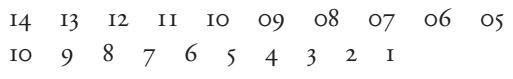

The paper used in this publication meets the minimum requirements of ANSI/NISO Z39.48-I992 (R 1997) (Permanence of Paper). 
FOR MY FAMILY 
This page intentionally left blank 